\title{
Women's empowerment and health: the role of institutions of power in Pakistan
}

\author{
N. Qureshi ${ }^{1}$ and B.T. Shaikh ${ }^{1}$
}

$$
\text { تحرين المرأة وأثره على حستها: دور المؤسسات ذات الملطة في باكستان }
$$

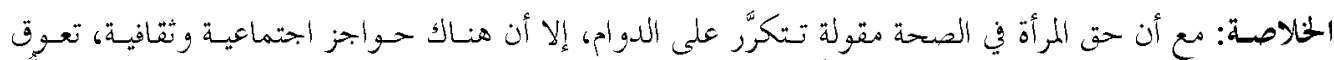

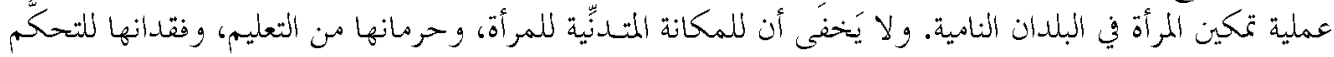

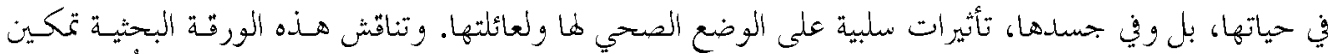

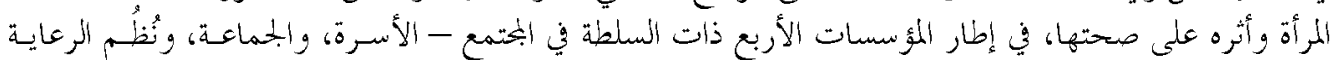

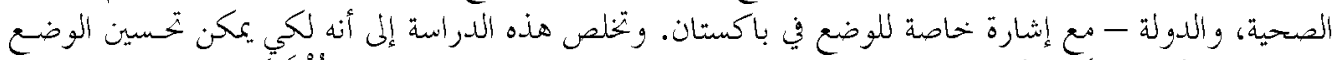

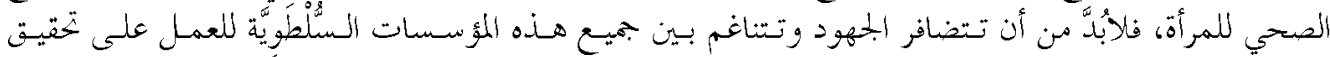

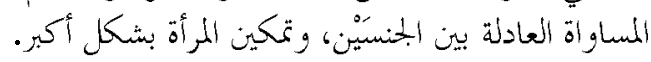

ABSTRACT Women's right to health has been reiterated many times. However, there are social and cultural barriers in developing countries that hinder their empowerment. Women's low status, deprivation of education and lack of control over their own lives and bodies have a negative impact on their health status and that of their families. This paper discusses women's empowerment and health within the framework of the 4 institutions of power in a society-family, community, health care systems and the state-with special reference to the situation in Pakistan. It concludes that to improve women's health status, concerted efforts are needed by all these institutions of power to work towards gender equality and the greater empowerment of women.

Autonomisation de la femme et santé : le rôle des lieux institutionnels de pouvoir au Pakistan RÉSUMÉ Le droit des femmes à la santé a été affirmé à de nombreuses reprises. Pourtant, il existe dans les pays en développement des barrières sociales et culturelles qui entravent le renforcement de l'autonomie des femmes. La péjorativité du statut des femmes, la spoliation de leurs droits à l'instruction et à la maîtrise de leur propre vie et de leur propre corps ont un impact négatif sur leur état de santé et celui de leur famille. Le présent article aborde la double question du renforcement de l'autonomie de la femme et de sa santé dans le contexte des quatre lieux de pouvoir traditionnels d'une société organisée, à savoir la famille, la collectivité, les systèmes de soins de santé et l'État, en accordant une attention particulière à la situation au Pakistan. L'article conclut que l'amélioration de la santé des femmes exige des efforts concertés entre ces différents vecteurs traditionnels de pouvoir, lesquels devront se concentrer sur la promotion de l'égalité des sexes et d'un « affranchissement " plus franc de la femme.

${ }^{1}$ Health Systems Division, Department of Community Health Sciences, Aga Khan University, Karachi, Pakistan (Correspondence to B.T. Shaikh: babar.shaikh@aku.edu).

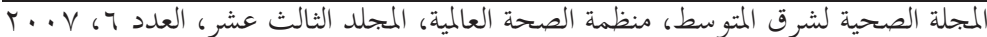




\section{Empowerment: defining the notion}

Researchers and reform activists have always advocated for gender equity and women's empowerment as prerequisites of social reform. These notions have been most strongly stressed by advocates of health reforms. Empowerment by definition is "a process by which the powerless get greater control over circumstances in terms of both ideology and resources" [1].

It is not so easy to apply this principle in practice, as embedded within communities are strong social and cultural values, norms and beliefs which, if challenged, may become a source of discord within the community. The values of a culture determine the role of women in its society and this phenomenon is global [2]. Worldwide, women play a pivotal role in raising children, caring for household members and running the home, in addition to their roles in the world outside the home. Hence, they may suffer an even greater physical, social and mental burden, and are especially deserving of appropriate health care.

Women's right to health has time and again been advocated. However, a multitude of social and cultural barriers have directly or indirectly hindered empowerment, reinforcing the negative impact on their health status [3]. Health systems, therefore, must develop an understanding of women's role and status within this complex sociocultural environment. Having acknowledged this, strategic health reforms need to be translated into actions for the enhancement of the lives of women. This is not just for their own sakes: there is evidence that the health systems in a country function more effectively if women are acknowledged as the crucial link between health services and the home [4].
This paper highlights the factors that contribute to gender inequities, that create barriers to women's empowerment and that compromise their health status in developing countries. These factors will be discussed within the framework of 4 institutions of power, i.e. family, community, health care systems and the state [5]. The impact of women's low status in some developing countries and its repercussions on their health will be discussed, with special reference to Pakistan. Furthermore, the paper highlights the potential for active input by women in promoting the health of their families and the wider community.

\section{A scenario of developing countries}

The factors determining women's health status have frequently been analysed for solutions to the problem of poor health, particularly in developing countries. Though much effort has been invested in researching women's health problems, macro-issues pertaining to the society they live in have often been ignored.

The 4 institutions of power-family, community, health care systems and the state [5] - play an important role in determining the health status of women. Family traditions and customs govern the lives of women. A lack of formal education and poor nutrition for girls, early marriage and multiparity are some of the determinants of ill-health and discomfort for women, [6]. On the part of the community, lack of social support networks, religious barriers and restrictions on women's mobility outside the home affect the process of seeking health and hinder women's health status [7]. The health care system is also important in determining women's health, including 
factors such as the low availability and poor quality of health care services, particularly obstetric care [8]. Finally, the state's lack of responsiveness to women's development is reflected in terms of inadequate provision of female health care providers in primary health care facilities, insufficient allocation of resources for girls' education and lack of awareness of gender issues in all sectors [9].

Most developing countries have been unable to devise any health reforms to work towards improving women's economic and social role in society. As the dismal health indicators show, we are faced with the challenges of consistently high rates of fertility, maternal mortality and morbidity and infant mortality $[10,11]$. The reasons are clear, as the World Health Organization definition of health - "a complete state of physical, social, mental and emotional wellbeing"-is never reflected in women's life experiences. From the beginning of her life, a girl child is given lower priority than a male child [12]. Owing to limited family income, girls have limited opportunities for formal education and are fed the least and the last, with malnourishment leading to a weakly-developed immune system and a greater chance of ill health [13].

Compounding the biological vulnerability of girls are many social realities reflecting women's lower social status, such as limited educational opportunities, unequal gender relations, inability to contribute to family decisions, domination of the husband's family and lack of control over their own lives and bodies [14].

Women are always considered subordinate to men, therefore they have a minimal say in matters related to marriage, pregnancy and family size [15]. Ironically, despite being the primary care providers of the family, women in developing countries are poorly equipped to deal with family ailments because they lack knowledge and awareness of health problems [16]. Besides the sociocultural barriers to women's role in health promotion, there is often negligence on the part of the health care providers and government organizations [17]. Negligence on the part of health care providers is seen in their attitudes towards female patients, the quality of health care services and affordability of medicines prescribed. On the part of the government, it is seen in the lack of concrete policies, the lack of intersectoral collaboration and unwillingness to empower women.

\section{Women's empowerment and health in Pakistan: the barriers; the constraints}

As in other south Asian countries, the situation of women's health is grim in Pakistan. Estimates of the maternal mortality rate (500/10 000 live births), infant mortality rate $(86 / 1000$ live births) and total fertility rate (5 children/woman) are still high [11]. In terms of the United Nations Development Programme's (UNDP) gender empowerment measurement (GEM), Pakistan lies 100 th out of 102 countries [18]. As mentioned before, all the 4 key institutions of power in society are accountable.

Traditions in a family play a fundamental role in developing a girl's physical, social and mental health status. Cultural values are embedded deeply in the family traditions, making her access to health care limited and most of the time dependent on the family's decision [19]. In terms of seeking health for herself, a woman has no control over decision-making, difficulty in accessing health centres and discomfort with communicating with male physicians. With a patriarchal system dominating, women are not allowed much liberty in terms of education and

المجلة الصحية لشرق المتوسط، منظمة الصحة العالمية، المجلد الثالث عشر، العدد Y، V... 
freedom of any kind, including freedom of movement [20].

Another factor inhibiting women's empowerment and better health status is lack of support from the husband's family [21]. In Pakistani society, the role of women as prescribed in Islam is often cited as a determinant of women's status. However, religious doctrine is often misinterpreted, leading to an unjustified restriction on women's mobility on the grounds that it is a threat to social and religious values and a distraction from household duties [22].

Barriers imposed by the community play a primary role in opposing women's empowerment, resulting in poor health indicators. Disregarding girls' education, restricting the decision-making power and the mobility of women and misinterpreting religious teachings are some of the many community-instituted barriers. For example, a woman in labour who suffers from complications may be unable to seek help if a male member of the family is absent. Support from the community is minimal or absent, and social support systems are lacking. Such a situation can lead to the death of the mother or the child or to future morbidity [23].

As for health care providers, the situation is no different. As women do not have any economic autonomy, the cost of health care is definitely a barrier to appropriate and quality health care seeking. Even if care is accessed, there is a communication gap between male physicians and female clients, whose problems are considered to be of lesser importance than males [24]. Due to a dearth of female health care providers, only $16 \%$ of women seek proper antenatal care and as few as $17 \%$ deliver in health facilities [11]. Most of the health care in Pakistan is sought from the private sector. Private practitioners thus have a crucial role to play in promoting women's health [25]. How- ever, the urban and formal setting of these clinics makes these health services difficult and costly to access for rural women [26]. Furthermore, male practitioners are neither gender-sensitized nor well trained to handle women's health problems; this brings a great deal of uneasiness among women clients [27].

In the state-owned health sector, there are also inadequate numbers of female health care practitioners employed in the government sector, a fact which restricts the female client's access to health care [28]. Village elders or community leaders often impede the activities of women practitioners and health professionals for various reasons, which may be political or incorrect interpretations of religious laws - for example, services may be seen as socioculturally inappropriate, there may be mistrust of the health workers and services or there may be myths and misperceptions about the services. In the public sector, primary health care centres are underutilized [29].

Another factor is short working hours so that health providers are often unavailable in the facilities. The ability to deliver quality health services also remains a big challenge in the Pakistani health sector because of the dearth of sound policies and poor implementation of public health programmes [30].

\section{What needs to be done?}

When proposing what needs to be done, we must first look at the role of family. Family heads should be sensitized to issues such as malnourishment among girls, the importance of girl's education, the appropriate age for marriage, greater child spacing, safe motherhood, etc. Private sector and nongovernmental organizations (NGOs) can play a key role in bringing this infor- 
mation to the communities they work in. A successful example of a community-based project run by civil society organizations with funding from the state is that of Tawana Pakistan, an endeavour to increase girls' school enrolment and provide them with a healthy diet at school. Such programmes need to be carried out with consistency and be sustained so that they lead to improved health status [20].

With respect to community issues, especially in rural areas of Pakistan, there is a need to listen to the community's views on social and health-related issues. Holding group discussions with all members of the community in order to highlight their issues would be a practical approach. Then sessions can be held to discuss the myths and taboos held in the community and address misinterpretations of religious teachings with the community leaders and clergymen. Community meetings could be held to encourage mothers-in-law and husbands to take a role in promoting women's health [31]. They need to be sensitized to their responsibility to look after a woman's needs and wants, and to give due regard to the rights to which she is entitled on both social and religious grounds.

The health care providers also need to be sensitized to women's health issues. Issues such as quality of services, long waiting hours, lack of female practitioners and apathy of physicians towards women clients ought to be addressed mutually by the state, NGOs, health care providers and the community. Monitoring of initiatives to support and promote women's health is imperative.

The state needs to contribute to the promotion of girls' education and other women's empowerment programmes. An inter-ministerial collaboration involving the Ministries of Health, Population Welfare, Education, Women's Development and
Social Development and all others concerned is needed, to invest in developmental programmes that lead to women's empowerment in society.

More schools for formal and non-formal education for girls could be one possible initiative. Better women's education has been associated with success in reducing infant and maternal mortality rates in the past decade $[19,25,32]$.

As for health, more female physicians need to be trained and employed in the public sector, and working hours need to be expanded so as to improve accessibility. Better status of women health care workers, better pay and working conditions and better incentives in the form of benefits to the family are essential.

There is a need to invest in skills development of women, for example by enabling them to set up small-scale businesses, thereby supplementing the family income and fostering financial independence. The micro-credit scheme in Kerala and the Grameen Bank's initiative in Bangladesh are some of the lessons to be learned [19,33].

Empowering women and improving their health status requires concerted efforts by the state, external donors, NGOs and women's health groups. The gender-based institutional rules need to be changed. The hierarchies of power should be transformed to work towards gender equality and to initiate the process of women's empowerment. The United Nations Millennium Declaration clearly acknowledges women's empowerment and gender equality as pillars of social justice in any society [34]. In response to this call and to join the efforts to achieve the Millennium Goals, the process needs to be initiated within communities not only for gender rights but also for the wellbeing and health of women, family and the entire community.

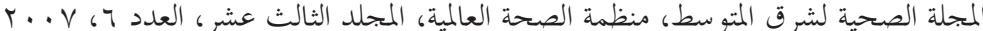




\section{References}

1. Sen G, Presser HB. Women's empowerment and demographic processes: moving beyond Cairo. Oxford, Oxford University Press, 1995.

2. Jackson PB, Mustillo S. I am woman: the impact of social identities on African American women's mental health. Women health, 2001, 32(4):33-59.

3. Zayas LH, McKee MD, Jankowski KR. Adapting psychosocial intervention research to urban primary care environments: a case example. Annals of family medicine, 2004, 2(5):504-8.

4. Gala C. Empowering women in villages: all-women village councils in Maharashtra, India. Bulletin of concerned Asian scholars, 1997, 29(2):31-45.

5. Kabeer N, Subrahmanian R. Institutions, relations and outcome: framework and tools for gender aware planning. Sussex, Institute of Development Studies, 1996.

6. Tinker AG. Improving women's health in Pakistan. Washington, DC, World Bank, Human Development Network, 1998 (Health, Nutrition and Population Working Paper Series).

7. Noorali R, Luby S, Rahbar MH. Does use of a government service depend on distance from the health facility? Health policy and planning, 1999, 14(2):191-7.

8. Hunte P, Sultana F. Health seeking behavior and the meaning of medications in Balochistan, Pakistan. Social science and medicine, 1992, 34(12):1385-97.

9. Pittman PM. Gendered experiences of health care. International journal for quality in health care, 1999, 11(5):397-405.

10. Castro R et al. A study on maternal mortality in Mexico through a qualitative approach. Journal of women's health and gender-based medicine, 2000, 9(6):679-90.
11. 2005 world health report. Make every mother and child count. Geneva, World Health Organization, 2005.

12. Winkvist A, Akhtar HZ. God should give daughters to rich families only: attitudes towards childbearing among low-income women in Punjab, Pakistan. Social science and medicine, 2000, 51(1):73-81.

13. Poverty in Pakistan: vulnerabilities, social gaps, and rural dynamics. Washington DC, World Bank, Poverty Reduction and Economic Management Sector Unit, South Asia Region, 2002.

14. Turkson R. Empowering women: analyses. Legal and policy barriers to family planning. Africa link, 1995, Apr:6-8.

15. Adamu YM, Salihu HM. Barriers to the use of antenatal and obstetric care services in rural Kano, Nigeria. Journal of obstetrics and gynaecology, 2002, 22(6):600-3.

16. Buckshee K. Impact of roles of women on health in India. International journal of gynaecology and obstetrics, 1997, 58(1):35-42.

17. Barry TM. Quality of care: from concept to action. A way ahead for sub-Saharan Africa FP and RH programmes. African journal of fertility, sexuality, and reproductive health, 1996, 1(2):85-91.

18. Women's health project, 1999. Investing in women's health: delivering better health care to all. Manilla, Philippines, Asian Development Bank, 2007 (http://www.adb. org/gender/practices/health/pakistan001. asp, accessed 22 July 2007).

19. Mahmood N, Kiani MF. Health care determinants of child survival in Pakistan. Pakistan development review, 1994, 33(4 Pt 2):759-71.

20. Sarwar B, Sheikh M. The girl child: a girls' empowerment initiative in Paki- 
stan. Planned parenthood challenges, 1995(2):37-43.

21. Rabbani F, Raja FF. The minds of mothers: maternal mental health in an urban squatter settlement of Karachi. Journal of the Pakistan Medical Association, 2000, 50(9):306-12.

22. Ibraz TS, Fatima A. Uneducated and unhealthy: the plight of women in Pakistan. Pakistan development review, 1993, 32(4 Pt 2):905-13.

23. Fikree FF et al. Health service utilization for perceived postpartum morbidity among poor women living in Karachi. Social science and medicine, 2004, 59(4):681-94.

24. Pallikadavath S, Foss M, Stones RW. Antenatal care: provision and inequality in rural north India. Social science and medicine, 2004, 59(6):1147-58.

25. Thaver I et al. Private practitioners in the slums of Karachi: what quality of care do they offer? Social science and medicine, 1998, 46(11):1441-9.

26. Gadit AA. Out-of-pocket expenditure for depression among patients attending private community psychiatric clinics in $\mathrm{Pa}$ kistan. Journal of mental health policy and economics, 2004, 7(1):23-8.

27. Stephenson R, Hennink M. Barriers to family planning service use among the urban poor in Pakistan. Asia-Pacific population journal, 2004, 19(2):5-26.

28. Islam A, Tahir MZ. Health sector reform in South Asia: new challenges and constraints. Health policy, 2002, 60:151-69.

29. Utilization of public health facilities in Pakistan. Islamabad, Government of Pakistan, National Health Management Information System, 2000.

30. Siddiqi $S$ et al. Pakistan's maternal and child health policy: analysis, lessons and the way forward. Health policy, 2004, 69(1):117-30.

31. Barnett B. Strategies needed to involve men, other family members. Family Health International Network, 1998, 18(4):12.

32. Samarasinghe V. Puppets on a string: women's wage work and empowerment among female tea plantation workers of Sri Lanka. Journal of developing areas, 1993, 27(3):329-39.

33. Khan MR. Microfinance, wage employment and housework: a gender analysis. Development in practice, 1999, 9(4):42436.

34. 2003 human development report. Millennium development goals: a compact among nations to end human poverty. New York, United Nations Development Programme, 2003. 